\title{
Remembering David Hartgen and Martin Wachs
}

\author{
Martin Richards ${ }^{1}$
}

Published online: 18 August 2021

(c) Springer Science+Business Media, LLC, part of Springer Nature 2021

Sadly, two of Transportation's past Editors have died, too young. Martin Wachs died on 11 April 2021, aged 79 and David Hartgen on 22 May 2021, aged 76.

Martin was one of the founding group of Editors joining the Journal in 1971 prior to its launch in 1971. He was then Associate Professor at the University of California, Los Angeles, moving on to appointment as Professor in UCLA's Department of Urban Planning before his retirement as an Editor on completion of Volume 5 No 2. But he continued to be closely associated with the Journal as a member of the Editorial Advisory Board until 2014 (Volume 42) and as an active and much valued reviewer of submitted papers.

Martin's career after leaving the Journal's Board of Editors included time as Director of the Institute of Transportation Studies at UC Berkeley, and as Director of the Transportation, Space and Technology Program at the RAND Corporation, He was Chairman of the Transportation Research Board's Executive Committee in 2000. Although formally retired, Martin remained professionally active, working on papers and mentoring students.

David Hartgen was a young researcher with the New York Department of Transportation when he joined the Board of Editors for Volume 5 No 2 as successor to Martin and became the Journal's North American Editor in 1977, Volume 7, following the retirement of Paul Shuldiner, the Journal's founding Editor in Chief. David retired from the Journal in 2015 on completion of Volume 42.

David had studied for his Doctorate under Martin Wachs at Northwestern. He moved from New York to the University of North Carolina Charlotte in 1989 where he established the University's Center for Interdisciplinary Studies, creating a program that combined engineering, planning, policy, geography and earth sciences. In 2007 he became Emeritus Professor and formed the Hartgen Group to pursue a career in consultancy. At the time of his death, David was moving towards retirement but was still very active professionally.

Both David and Martin made major contributions to research and teaching over the long and active careers, and the Editors and Publisher of Transportation are very grateful for their work for Transportation, as Editors, authors and reviewers. Their sympathies are with David's and Martin's widows, Linda and Helen, and with their wide families.

Martin Richards.

Editor, Volumes 1-5, Editor in Chief Volumes, 6-40.

Martin Richards

Zürich, Switzerland 
Publisher's Note Springer Nature remains neutral with regard to jurisdictional claims in published maps and institutional affiliations. 